解 説

\title{
光応答性ポリマー材料表面の in situ 局所制御
}

\author{
須 丸 公 雄*, 金 森 敏 幸* \\ *(独) 産業技術総合研究所 バイオニクス研究センター(テ305-8565 茨城県つくば市東 1-1-1 つくば中央第 5)
}

\section{In Situ Control of Photo-Responsive Polymer Surface}

\author{
Kimio SUMARU* and Toshiyuki KANAMORI* \\ * Research Center of Advanced Bionics, National Institute of Advanced Industrial Science and Technology (Tsukuba \\ Central 5 th, 1-1-1 Higashi, Tsukuba-shi, Ibaraki 305-8565)
}

Keywords : Photo-Responsive Polymer, Light Irradiation, Cell Patterning, Hydrogel

\section{1.はじめに}

光照射によって化学構造が変化し, それにともないその性 質も変化する分子材料はフォトクロミック材料と呼ばれ, 特 に可逆的な変化を示すものとしては, スピロピラン類, アゾ ベンゼン類, ジアリールエテン類などが知られている1)。局 所的・遠隔的・即時的に作用させることのできる光によって 制御できることから, これらの応用に関する研究がさまざま な分野で盛んに行われ, その一部は CD-R や DVD-R などの 光記録媒体としてすでに広く実用化されている。また，ポリ マー材料をこうしたフォトクロミック材料で修飾し, その物 性に光応答性を付与する試みも古くからなされ, 数々の興味 深い研究結果が報告されている2),3)。本稿では, 光応答性ポ リマー材料の表面物性に関する最近の研究動向について, 細 胞接着性および表面形状の光制御を目指した筆者らの試みを 中心に概説する。

\section{2. 基材表面の細胞接着性}

動物細胞は浮遊性と足場依存性の 2 つに大別され, そのほ とんどは組織や器官を構成する足場依存性細胞で占められて いる。生体内 (in vivo) においてこれらは, 何らかの「足場」 に接着した状態でのみ細胞固有の機能を発現し, これらを生 体外 (in vitro) で生存させるためには，培養ディッシュなど の細胞接着性に富む基材の上で培養する必要がある。その培 養基材としては, 一般的にポリスチレンやポリオレフィンな どのポリマー材料が用いられるが, 多くの場合, 必要な細胞 接着性を得るために, コロナ放電やタンパクコートなど, 何 らかの表面処理を施したものが用いられる。また，ポリエチ レングリコール (PEG)やポリアクリル酸といつた水和性の 高いポリマーを担持させると, 細胞の接着が強く阻害される ことが知られている。東京女子医大の岡野らは, 温度変化に 応答してその水和性が著しく変化する感温性ポリマーからな るゲルを表面に担持した培養基材を開発し，この上で培養さ れた足場依存性細胞を傷めることなく回収する技術を確立し た ${ }^{4)}$ 。この技術は再生医療の現場において実際に臨床応用さ
れ，さらに近年，この技術に基づいて設立されたベンチャー 企業によって感温性培養基材が上市 ${ }^{5}$, 刺激応答性ポリマー をバイオ分野に応用した好例として注目されている。

このように, 基材表面の細胞接着性がその水和性に大きく 依存することは, 細胞を用いたこれまでのさまざまな研究に よって明らかになっている。上に述べたと抢り, 光照射に よって物性変化を示すポリマーに関する研究は以前からなさ れており，ポリマー材料の表面の親水性・疎水性を光で制御 する試みについても, 少数ながら研究報告がなされている ${ }^{6)}$ 。 このような状況において筆者らは, 光応答性ポリマーの特性 を，生きた細胞の接着性をその場で制御する技術に応用する ことを目指し研究を進め, いくつかの光応答性培養表面の開 発に成功している。それらの中から以下では, 培養環境下で 光照射するだけで, 細胞接着阻害性を解除することが可能な 光追記型培養表面について, 最近の研究成果を紹介させてい ただく。

\section{3. 光追記型培養表面}

この培養基材は, 細胞接着阻害性を有する PEG (上述) , ニトロスピロピランで修飾された光応答性ポリマー (pNSpMMA)を介して表面に固定化したものである(図 1 )。ニト ロスピロピランはフォトクロミック分子材料の一つであり, 波長 $365 \mathrm{~nm}$ の紫外光照射によって水和性の高い構造に変化 することが知られている。水や培地の中でこの基材に光を照 射すると, 光応答性ポリマーの水和性が増加して膨潤, 基材 表面に担持されていた PEG が解放されることにより, 細胞 が接着できるようになる ${ }^{7), 8)}$ 。この基材表面に細胞分散液を 導入すると, 先に照射した領域に選択的に細胞が接着, 引き 続き培養することで細胞は照射域の範囲内で増殖する。何ら かのパターンに沿って局所的に光照射を行えば，そのパター ンに沿って細胞が配置され, いわゆる細胞パターニングを簡 便に行うことができる。PEGの細胞毒性はかなり低く, 細 胞融合などを行う場合に高濃度で添加されても, あまり細胞 活性を損ねないことが知られている上, 基材表面に担持され ている PEG は極めて微量で, 光照射によって培地中に移行 


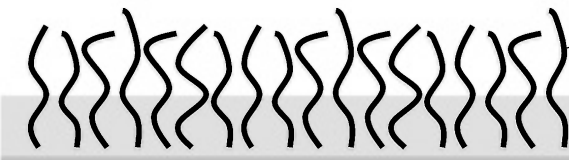

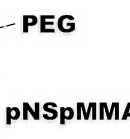

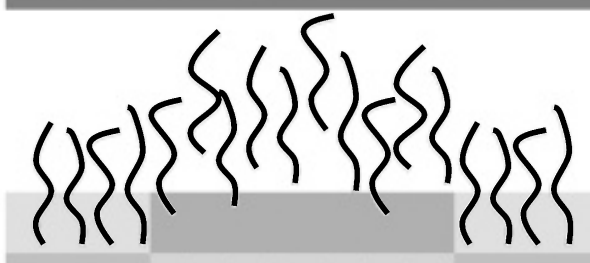

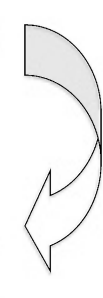

light irrad.

図 1 光追記型培養表面における細胞接着阻害の光解除

したわずかな PEGも，細胞播種前に洗い流すことで取り除 かれる。また，さらなる化学的な処理が不要なので，すでに 細胞がパターンに沿って培養されている状態においても，こ れらの細胞にほとんどダメージを与えることなく，あとから 光照射を行うことにより細胞接着領域を追加すること (光追 記)が可能である。

培養環境中で細胞接着が自在に制御できるこうした利点を 最大限に利用するためには，顕微鏡観察しながら視野の任意 の領域に光照射する手段が必要となる。そこで筆者らは，工 ンジニアリング・システム侏と共同で，パソコンによって制 御可能なパターン照射ユニットと CCD ユニットを倒立型生 物顕微鏡の光学系に組み込み，微小パターン照射システムを

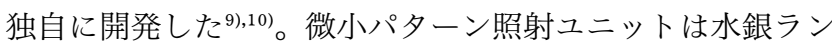
プを光源とし, DMD 方式で所定のパターンを投影, 顕微鏡 の対物レンズを通じて，ミクロンスケールの精度で任意のパ ターンを観察する対象に照射する。また， CCD ユニットの 撮影領域と照射ユニットの照射領域をプログラム上で対応さ せることにより，パソコンのモニタに映し出された観察像の 上でマウスを用いて照射したい領域を自由に指定し，ステー ジ上に置かれたサンプルの対応する個所に光照射することも できる。図 2 は，この微小パターン照射システムを用いて， 予め幅 $80 \mu \mathrm{m}$ の線状パターンで照射した光追記型培養表面 に, MDCK (イヌ腎臓由来)細胞を播種し, 数時間培養して から非接着の細胞を除去, さらに半日程度培養した後の細胞 の様子を示している。局所的な光照射によって細胞が接着可 能になった領域は，強い細胞接着阻害性を示す PEG で取り 囲まれており, 接着している細胞はその後数日間培養した後 もそこに安定に閉じこめられることが確認された。

さて，足場依存性細胞と一口に言っても，その形状，大き さ, 接着性はまさに千差万別で, 1 種類の光追記型培養基材 を用いて，それらの接着性を同様に光制御することは難しい。 しかし，この培養基材の細胞接着性は，基材上に担持させる PEGの量および分子量を変えることにより，容易にチュー ニングすることが可能で，扱う細胞に応じて適当なものを用 いれば，たいていの足場依存性細胞をこの方法でパターニン グすることができる。筆者らによるこれまでの検討の結果， 上述の MDCK に加えて, 研究室で保有するすべての足場依 存性細胞 (CHO, HeLa, HepG 2, MEF，3 T 3) に，同様 の光追記型培養表面による細胞接着制御が適用できることを

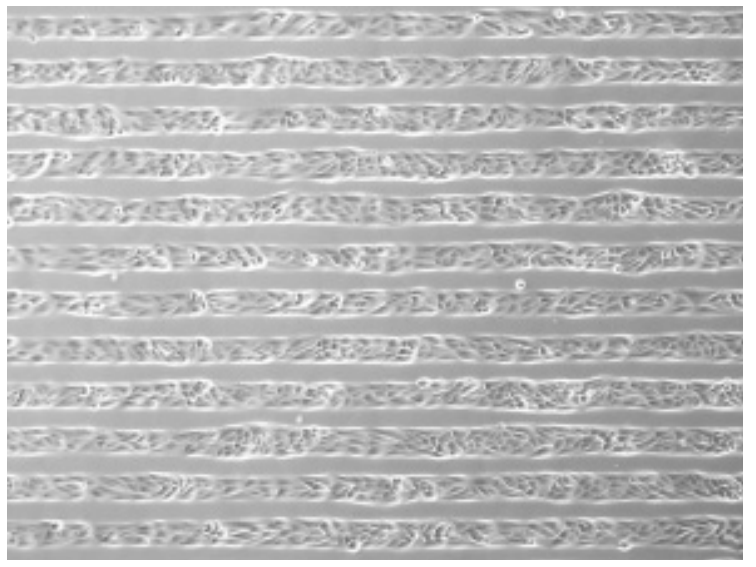

図 2 光追記型培養表面上にパターニングされた MDCK 細胞

確認している。また，このような細胞パターニングは，足場 依存性細胞の特性を解析する手段として, 以前から盛んに検 討されているが, 従来技術では細胞播種後にパターンを変更 することが原理的に不可能であるのに対し，この手法では， 細胞接着領域を培養環境下で自在に追加することが可能なの で，この操作を繰り返すことにより，複数種類の細胞を任意 のパターンに配列して共培養する系を，容易に構築すること ができる。このことを示すデモンストレーションとして筆者 らは，予め染め分けた CHO-K 1 細胞を，この培養基材と前 節で述べた光照射装置を用い，異なる細胞をそれぞれ異なる パターンに沿って配列させて, これまでにない共培養系が実 現できることを初めて実証した ${ }^{11,12)}$ 。細胞と細胞，あるいは 細胞と基材の間の相互作用が，生体組織としての細胞の機能 発現において非常に重要であるが，こうした共培養系の構築 は，細胞培養の環境をより生体内の環境に近づけうる有効な 手段であると考えられる。

\section{4. 材料形状の光応答}

ポリマー材料の表面物性に加えて，その形状を光で制御す る研究も盛んに行われている。とくにフォトニック材料の研 究分野においては, アゾベンゼンを含むポリマー薄膜(常温 で固体)の表面形状が光照射によって変化する現象が，材料 表面の形状を任意制御する要素技術として注目されている。 強度や偏光状態にサブミクロンスケールの分布を有する光を 照射すると，その分布に沿った凹凹レリーフが薄膜表面に形 成されるこの現象は, 1995 年に発見されて以来 ${ }^{13), 14)}$, 現在 もさまざまな応用に向けて盛んに研究が行われている ${ }^{15), 16) 。 ~}$ その形成メカニズムの全容はまだ明らかになっていないが, フォトクロミック色素であるアゾベンゼンの光異性化にとも なう構造や分子間相互作用の変化，ポリマーの熱運動といっ た分子レベルで物質移動が起こる素過程によることが推察さ れている。こうしたサブミクロンスケール形状変化において は，分子レベルの物質移動が重要な役割を果たしうるが，こ うした素過程に基づく物質移動は非常に遅く, 現実的な制御 時間(数分以内)の間に, 数 $\mu \mathrm{m}$ 以上のマクロな形状変化を もたらすためには, 光によってバルク的な体積変化が引き起 こされる必要がある。

筆者らは, 感温性ポリマーであるポリ $(N$-イソプロピルア 
クリルアミド)を，フォトクロミック分子であるスピロピラ ンで修飾して調製した光応答性ポリマーが，酸性水溶液中に おいて顕著な光応答性脱水和を示すことを見出した ${ }^{17), 18)}$ 。酸 性水溶液中暗所下において，スピロピラン残基のほぼすべて が開環化・プロトン化し, 鮮やかな黄色を呈する一方で, 波 長 $436 \mathrm{~nm}$ の青色光を照射すると色素残基がプロトン解離を ともなって閉環化して無色となる。 $30^{\circ} \mathrm{C}$ 前後の温度では，ス ピロピラン残基のこの構造変化がポリマーネットワーク全体 の脱水和を誘起，色素導入率がモノマー分率でわずか 1 mol\%程度であるにもかかわらず，顕著な相分離が引き起こ されるのである。さらにこのポリマーからなるハイドロゲル を調製, 酸性水溶液中で膨潤させた状態のゲルに青色光を照 射すると， $25^{\circ} \mathrm{C}$ から $30^{\circ} \mathrm{C}$ 温度範囲では素早く収縮するこ と，その後暗所下で放置すると徐々に元の状態に戻り，同様 の光応答収縮を繰り返し行えることが，これまでの我々の研

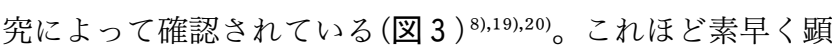
著な体積変化を可視光照射によって可逆的に誘起できるハイ ドロゲルはこれまでに報告例がなく，マクロな形状変化を光 で誘起できる特性を活用したさまざまな応用が期待されてい る。

\section{5. ゲル表面の 3 次元形状の光自在制御}

そこで筆者らは，このポリマーからなる厚さ $250 \mu \mathrm{m}$ のゲ ルシートを，メタクリル基を表面に有するガラス基板上で in situ 重合することにより調製した。ゲルシートの片面は ガラス基板の表面に固定されているため，酸性暗所下で膨潤 させたシートの局所領域に光照射を行うと，その部分のみで ゲルシートの高さが減少することが期待される(図 4 )。微小 パターン光照射装置を用いて，所定のパターンで光照射を 行った結果，わずか 1 秒程度の光照射によって，シート表面 に明瞭な凹凸レリーフ像が刻まれることが確認された(図 $5)^{22)}$ 。光照射域におけるゲルシートの厚さの経時変化を調 べたところ，光照射直後にゲルは収縮を開始，数分の間にゲ ルシートの厚さが元の約半分にまで減少することが明らかに なった。その後 10 分程度収縮状態を安定に保持した後，照 射によって異性化したスピロピランが熱的に元の開環プロト

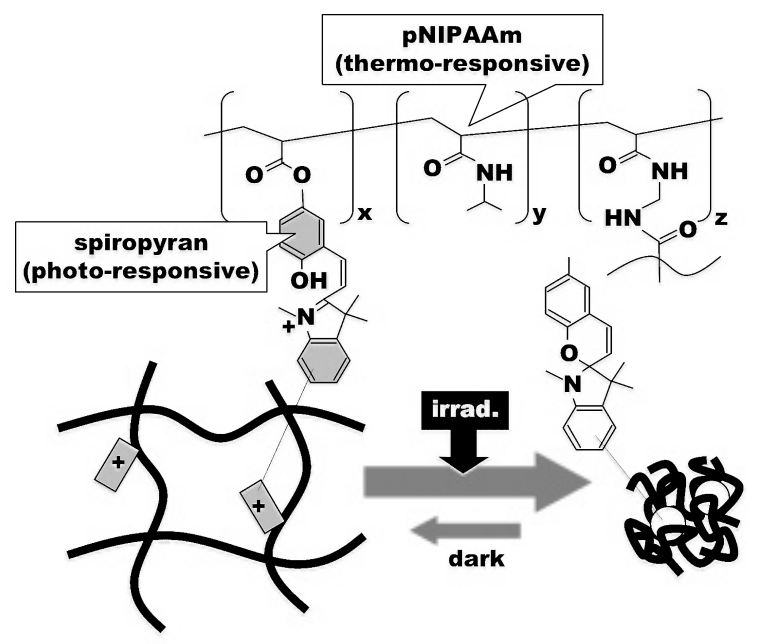

図3 光応答性ポリマーからなる架橋八イドロゲルの構造と光応 答収縮を示す模式図
ン化体に戻るのにともない, 約 2 時間かけて元の厚さまで回 復した ${ }^{21)}$ 。収縮状態の領域に対して適当なインターバルで光 照射を繰り返すか，連続的に照射し続けるか(この場合は強 度はかなり低くてよい)することで，その状態を永続的に保 持することが可能である。また，回復後のゲル表面に再びパ ターン光を照射することにより，全く異なる形状を刻むこと もできる。 $\mu \mathrm{m} レ$ レ゙の精度で明確に刻まれ，照射後安定に 保持されるた凹凸形状は，ゲルシートの収縮が単なる光熱変
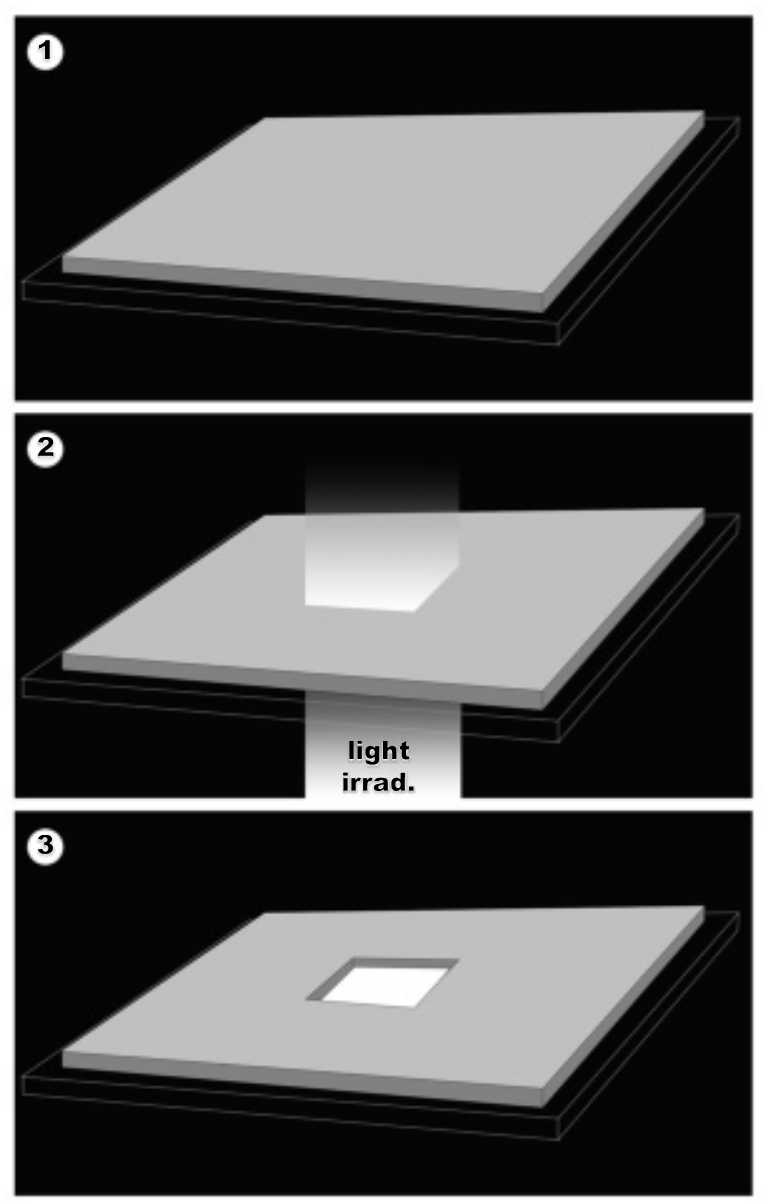

図 4 光応答性ゲルシート厚さの光照射による局所制御を示す模 式図

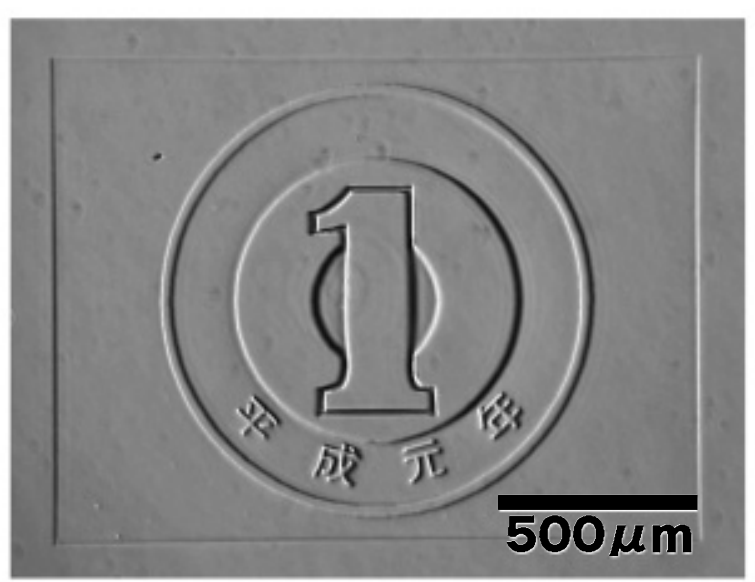

図 5 パターン光照射によって光応答性ゲルシート表面に形成し た微小レリーフ 

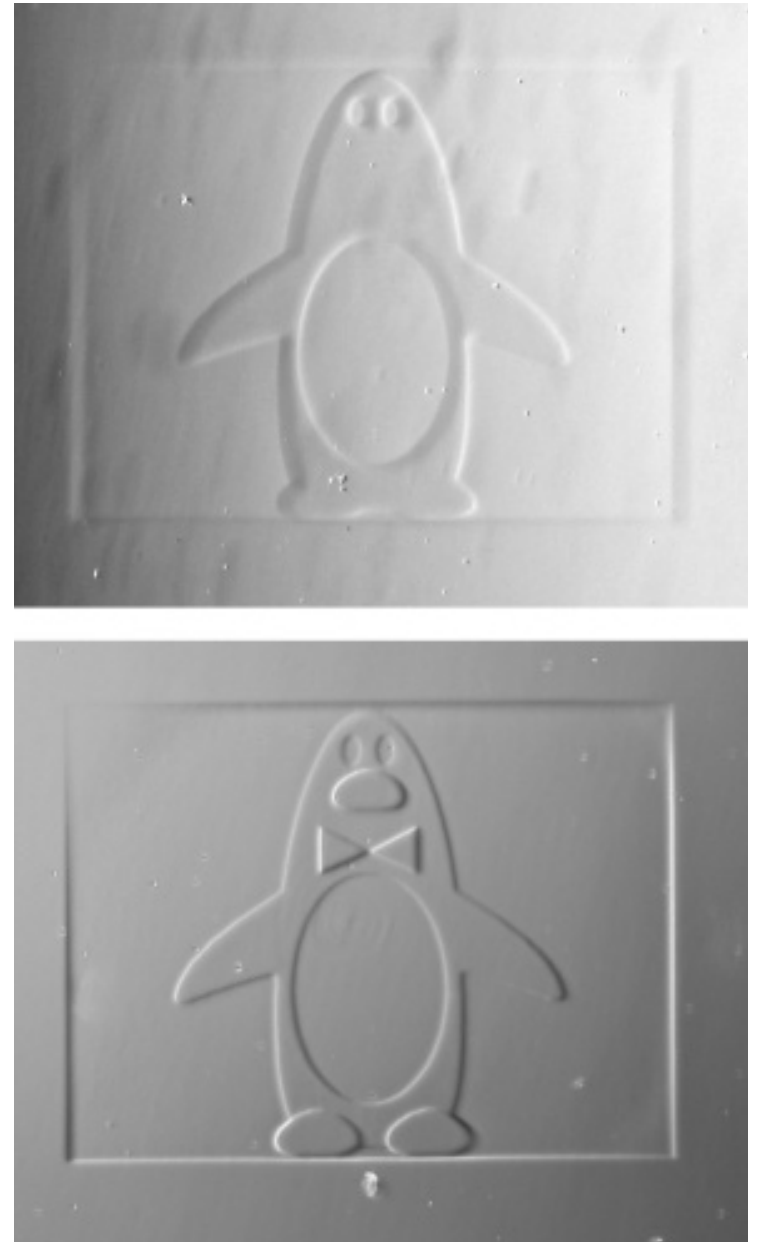

図 6 多階調パターン光照射による微小レリーフの形成過程

換(「ヒートモード」)による熱的相転移に基づくものではなく, スピロピランの光異性化に基づく純粋な「フォトンモード」 のプロセスであることを明らかに示している。

さらに 3 次元形状の自在制御性を実証するために, 多階調 の光照射による表面形状の制御も行った。その結果を図 6 に 示す。まず, 酸性水溶液中暗所下で膨潤させたゲルシートに 対して, 所定のパターンに沿って光照射を行うと, 上述の通 り照射域で局所的に収縮が生じた(図 6 上)。その後別のパ ターンに沿って光照射を行うことによって, 合計 3 通りのエ ネルギー密度で照射された領域をゲルシート上に形成，3階 調の高さからなるレリーフ像が形成できることが確認された (図6下)。照射回数を増やす, あるいは, 多階調の強度分布 を有するパターンの照射を行うことで, さらに精密な形状制 御を行うことが可能である。現在，こうした材料形状の局所 制御性を利用して, 細胞などの微小な対象の独立・並列的操 作, マイクロ流体システム中における物質移動の自在制御な ど22)への応用についても研究を進めている。

\section{6. おわりに}

昨今, 細胞工学の急速な伸展にともなって細胞操作のニー ズがますます多様化し，新たな細胞操作技術に対するニーズ がにわかに高まっている ${ }^{23)}$ 。また, 反応・分析装置をチップ 上に構築し, 集積化によってシステムを小型化することに加 え， $\mu \mathrm{m}$ スケールの微小な系に固有の化学プロセスの有用性
を積極的に活用する試みが，盛んになされている ${ }^{24), 25)}$ 。上述 の通り，光は対象に対して局所的・遠隔的・即時的に作用さ せることができる唯一の制御手段であり，これによって物性 が制御される機能性表面は, 細胞や微粒子, マイクロバルブ といった多数の微小な対象を独立かつ並列的に制御する上で, 重要な要素技術となることが大いに期待される。

\section{謝 辞}

本研究は, 科学技術振興機構 (JST) 大学発ベンチャー創出 推進事業(平成 17 年度採択課題) および平成 17 年度 NEDO 産業技術研究助成事業の助成を受けて行われた。

(2007-7-2 受理)

\section{文献}

1) 入江正浩 ; 高分子, 47, 449 (1998).

2) M. Irie, M.and D. Kungwatchakun; Macromolecules 19, 2476 (1986).

3 ) R.Kroger, H. Menzel and M. L. Hallensleben ; Macromol. Chem. Phys. 195, 2291 (1994).

4 ）岡野光夫, 大和雅之; 日経サイエンス, 33, 43 (2003).

5 ) http : //www.cellseed.com

$6)$ H. Akiyama and N. Tamaoki; J. Polym. Sci. A Polym. Chem., 42, 5200 (2004).

7 ) Y. Tada, K. Sumaru, M. Kameda, K. Ohi, T. Takagi, T. Kanamori and Y. Yoshimi ; J. Appl. Polym. Sci., 100, 495 (2006).

8 ）須丸公雄；ケミカルエンジニヤリング, 51, 378 (2006).

9 ）須丸公雄；医学のあゆみ, 218, 129 (2006).

10) K. Sumaru, J. Edahiro, Y. Ooshima, T. Kanamori and T. Shinbo ; Biosens. Bioelectron., 22, (9), 2356 (2007).

11）須丸公雄, 金森敏幸 ; 動物実験代替のためのバイオマテリア ル開発 (酒井康行編), シーエムシー出版, 印刷中.

12）須丸公雄, 金森敏幸 ; レーザー研究, 印刷中.

13) P. Rochon, E. Batalla and A. Natansohn ; Appl. Phys. Lett., 66, 136 (1995).

14) D. Y. Kim, S. K. Tripathy, L. Li and J. Kumar ; Appl. Phys. Lett., 66, 1166 (1995).

15) N. Zettsu, T. Fukuda, H. Matsuda and T. Seki ; Appl. Phys. Lett., 83, 4960 (2003).

16) C.-D. Keum T.Ikawa, M. Tsuchimori and O.Watanabe ; Macromolecules, 36, 4916 (2003).

17) K. Sumaru, M. Kameda, T. Kanamori and T. Shinbo ; Macromolecules, 37, 4949 (2004).

18) K. Sumaru, M. Kameda, T. Kanamori and T. Shinbo ; Macromolecules, 37, 7854 (2004).

19) K. Sumaru, K. Ohi, T. Takagi, T. Kanamori and T. Shinbo ; Langmuir 22, 4353 (2006).

20）須丸公雄；膜, 30，(3）132（2005）.

21） A. Szilagyi,K. Sumaru,S. Sugiura, T. Takagi, T. Shinbo, M. Zrinyi and T. Kanamori ; Chem. Mater., 19, 2730 (2007).

22) S.Sugiura, K. Sumaru, K. Ohi, K. Hiroki, T. Takagi and T. Kanamori ; Sens. Actuators A, in press.

23）岡野栄之, 阿形清和 ; 細胞工学, 19, 368 (2000).

24）北森武彦, 庄子習一, 馬場延信, 藤田博之 ; マイクロ化学チッ プの技術と応用（丸善, 2004）

25） T. Thorsen, S. J. Maerkl and S. R. Quake ; Science, 298, 580 (2002). 